\title{
Molecular investigations of viral meningitis among HIV-infected adults in Accra, Ghana
}

Emmanuel Frimpong Adjei ${ }^{1,2}$, Theophilus Korku Adiku², Gifty Mawuli ${ }^{1}$ and Joseph Humphrey Kofi Bonney ${ }^{1 *}$

\begin{abstract}
Objective: Meningitis is one of the leading causes of death among patients living with the human immunodeficiency virus (HIV) in sub-Saharan Africa. Based on clinical presentations alone, the different types of meningitis may not be distinguished from each other, consequently accurate laboratory diagnosis is extremely essential. Viruses such as Enteroviruses (EV), Mumps virus (MuV) and Herpes Simplex Virus-1 (HSV-1) are implicated in cases of meningitis. We sought to detect and characterize viral aetiologies of meningitis among HIV-infected adults with the use of molecular tools.

Results: As a subset of a main research work, cerebrospinal fluid specimens were collected from a cross-section of HIV patients at the Fevers Unit of the Korle Bu Teaching Hospital with clinical features suggestive of meningitis but without laboratory confirmation. Laboratory investigations were performed with the use of the real time polymerase chain reaction for pan EV, MuV and HSV-1. None of the viruses investigated in this study was found to be positive for meningitis. However, lymphocytic pleocytosis, normal glucose and elevated protein levels were observed in some of the study participants.
\end{abstract}

Keywords: Human immunodeficiency virus, Meningitis, Cerebrospinal fluid, Viral aetiology

\section{Introduction}

Viral meningitis is a central nervous system (CNS) related condition which is self-limiting but associated with high rate of morbidity among immunocompromised populations $[1,2]$. In general, meningitis as a condition has been associated with several aetiologies such as bacteria, parasites, fungi or viruses [3-5]. Different viral agents have been implicated as aetiologies of viral meningitis with the prevalence recorded in several studies [6-9]. Enteroviruses, particularly echovirus 22 and 23 (also known as Human parechoviruses type 1 and 2) have been documented as the second cause of viral meningitis in young children $[10,11]$. Additionally, Herpes Simplex

\footnotetext{
*Correspondence: Kbonney@noguchi.ug.edu.gh

1 Department of Medical Microbiology, School of Biomedical and Allied Health Sciences, College of Health Sciences, University of Ghana, Accra, Ghana

Full list of author information is available at the end of the article
}

Virus-1 (HSV-1) and Mumps virus (MuV) are also known to cause meningitis [12-15].

The possibility of a viral aetiology of meningitis usually arises once bacterial and fungal stains or cultures of cerebrospinal fluid (CSF) are negative. Amidst the myriad of illnesses presented by a patient with meningitis, it is documented that viral meningitis is often associated with lymphocytic pleocytosis, normal glucose and elevated protein $[3,16,17]$. Based on clinical presentations alone, the different causes of meningitis may not be clearly known which makes the proper management and treatment of the patients difficult. Accurate diagnosis is therefore essential and will help reduce the indifferent use of antibiotics, hospital visits and medical bills in such a resource limited setting.

Nucleic acid amplification techniques provide a rapid and specific aetiological diagnosis for cases of meningitis. Other diagnostic assays such as culture and immunoassays are less sensitive and take a longer time for results to be attained. Further to that, virus isolation attempts

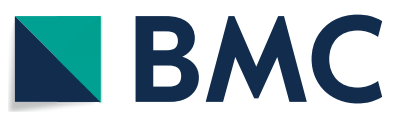

(c) The Author(s) 2018. This article is distributed under the terms of the Creative Commons Attribution 4.0 International License (http://creativecommons.org/licenses/by/4.0/), which permits unrestricted use, distribution, and reproduction in any medium, provided you give appropriate credit to the original author(s) and the source, provide a link to the Creative Commons license, and indicate if changes were made. The Creative Commons Public Domain Dedication waiver (http://creativecommons.org/ publicdomain/zero/1.0/) applies to the data made available in this article, unless otherwise stated. 
by culture methods have not been successful for all the known meningitis-causing viruses [18].

Predominantly, more studies in Ghana have documented the contribution of other microbial agents including bacteria and parasites as aetiologies of meningitis [19-21, 25], with limited work on viral agents implicated in neurologic infections. Cases of clinically suspected meningitis are recorded at the FU of KBTH but confirmation and further identification of the aetiological agents are rarely done. In a broader study [25], we investigated and detected varied microbial pathogens in 51 out of $84 \mathrm{HIV}$-infected adults with provisional diagnosis of meningitis in the following distribution: Epstein-Barr virus 28.6\%, Toxoplasmosis 25.0 and 2.4\% each for Cytomegalovirus and Cryptococcus. This addedon research sought to use molecular diagnostic tools to determine the occurrence of other known viral aetiologies documented to cause and exacerbate meningitis in especially immunocompromised patients.

\section{Main text}

\section{Methods}

This study is an addition to a main research work in which other aetiological agents that could cause meningitis were investigated. This current study takes into consideration three viruses (EV, MuV and HSV-1) which are also known to cause meningitis.

\section{Study area and subjects}

This study was conducted at the Fevers' Unit (FU) of the Korle Bu Teaching Hospital (KBTH) in Korle Bu, Accra from August 2014 to January 2016. Korle Bu Teaching Hospital is a referral hospital with a 2000 patient bed capacity and 17 clinical and diagnostic departments and the largest tertiary health facility in Accra which is the capital city of Ghana. In all, eighty (80) patients who had been tested and confirmed to be HIV positive and with clinical symptoms consistent with meningitis were recruited for this study. All patients were adults ( $\geq 18$ years). As meningitis may present with diverse clinical symptoms such as headache, fever, stiff neck, neurologic symptoms, abnormal behaviour, seizure, nausea, tachycardia, photophobia and others, it was expedient to have a clear definition for cases. Trained health staff screened and enrolled patients who met the standard case definition of meningeal symptoms of stiff-neck, fever and headache as well as cerebrospinal fluid pleocytosis, with no laboratory evidence of bacterial or fungal organisms. .

\section{Sample collection}

The archived clinical specimens collected from our previous study [25] were used for this added-on research work. For each patient, the CSF specimens were collected were kept in two separate bottles (sterilized Bijou sample container and a Shutterstock Sodium fluoride containing bottle; Mersk KGaA, Darmstadt, Germany). The CSF specimens in fluoride bottles were used to ascertain CSF biochemical parameters at the Central Laboratory of $\mathrm{KBTH}$ and that in the Bijou bottle was used to perform initial microbiological analyses such as CSF cell count and differential at the Medical Microbiology Department research laboratory of University of Ghana. Residual specimens were then cryopreserved in a $-20^{\circ} \mathrm{C}$ freezer until they were transported in a cool box with ice packs to the Noguchi Memorial Institute for Medical Research (NMIMR) for further processing.

\section{Biochemical data}

Cerebrospinal fluid biochemical parameters that were measured included White cell counts and differential, total protein levels, glucose levels and globulin assay (Table 1) with the use of an automated hematological analyzer (Sysmex XN-1500, Sysmex, Europe). Glucose level in the CSF was measured using the Glucose oxidase method [26]. A turbidimetric method [27] was used

\section{Table 1 Laboratory findings of CSF samples based} on cellular and biochemical characteristics

\begin{tabular}{|c|c|c|}
\hline Variables & Frequency & Percentage \\
\hline \multicolumn{3}{|c|}{ WBC differential [(cells $\left./ \mathrm{mm}^{3}\right)^{3}$; (normal range)] } \\
\hline Lymphocytes & 30 & 75.00 \\
\hline PMNs & 7 & 17.50 \\
\hline PMNs/lymph & 3 & 7.5 \\
\hline \multicolumn{3}{|l|}{ CD4 count (cell/mm³) } \\
\hline Mean/SD & $1383.96 \pm 3285.23$ & \\
\hline Range[(min-max); (normal range)] & $(1-979)$ & \\
\hline$<200(500-1500)$ & 53 & 66.25 \\
\hline$>200(500-1500)$ & 14 & 17.50 \\
\hline \multicolumn{3}{|l|}{ CSF-glucose (mmol/l) } \\
\hline Mean/SD & $2.9025 \pm 1.22$ & \\
\hline Range [(min-max); (normal range)] & $(1.00-8.80)$ & \\
\hline$<2.5(2.5-4.4)$ & 21 & 26.25 \\
\hline$\geq 2.5(2.5-4.4)$ & 59 & 73.75 \\
\hline \multicolumn{3}{|l|}{ CSF-protein (g/l) } \\
\hline Mean/SD & $1.1498 \pm 1.56$ & \\
\hline Range [(min-max); (normal range)] & $(0.03-9.86)$ & \\
\hline$\leq 0.45(0.15-0.45)$ & 26 & 32.50 \\
\hline$>0.45(0.15-0.45)$ & 54 & 67.50 \\
\hline \multicolumn{3}{|c|}{ CSF globulin (normal range -3 to $12 \%$ of CSF total protein) } \\
\hline Positive & 48 & 60 \\
\hline Negative & 29 & 36 \\
\hline
\end{tabular}

$0-5$ cells/ $\mu \mathrm{l}(<2$ polymorphonucleocytes [PMN]) normal cell counts do not rule out meningitis or any other pathology

Mean/SD values and the normal ranges for the variables considered are in italics 
to ascertain the protein levels of the CSF samples using trichloroacetic acid.

\section{PCR assays: nucleic acid extraction, quantification and amplification}

The extraction and purification of nucleic acid was performed using QIAamp Viral Mini Extraction Kit (Qiagen, Hilden, Germany). Nucleic acid was extracted from $140 \mu \mathrm{l}$ of CSF samples from enrolled participants. The concentration and purity of the nucleic acid was measured using the NanoDrop 2000c (Thermo Scientific, Massachusetts, USA).

Realtime reverse transcription-PCR (rRT-PCR) was performed for EV and Muv with the reagent AgPathID $^{\mathrm{TM}}$ One Step RT-PCR Kit (Applied Biosystems, California, USA). Samples were tested in a $25 \mu$ l reactions mixture including $5 \mu \mathrm{l}$ nucleic acid as template, $12.5 \mu \mathrm{l}$ of $2 \times$ RT-PCR Buffer, $1 \mu$ l of reverse transcriptase mix, $0.5 \mu \mathrm{l}$ of each of the forward and reverse primers and probe sets. Nuclease free water $(5 \mu \mathrm{l})$ was added to make up the mixture to $25 \mu \mathrm{l}$. The oligo sequences of primers and probes sets used in this study are detailed in Table 2.

Amplification was performed using the Applied Biosystems ${ }^{\circledR} 7300$ Real time PCR instrument (Life Technologies, California, USA). Cycling conditions for all primer and probe sets consisted of a reverse transcriptase step at $45{ }^{\circ} \mathrm{C}$ for $45 \mathrm{~min}$, followed by a Taq polymerase activation step at $95^{\circ} \mathrm{C}$ for $10 \mathrm{~min}$ and then 40 cycles at $95{ }^{\circ} \mathrm{C}$ for $15 \mathrm{~s}$ (denaturing) and $60^{\circ} \mathrm{C}$ for $1 \mathrm{~min}$ (annealing and extension step). Data were collected at the $60{ }^{\circ} \mathrm{C}$ for $1 \mathrm{~min}$ (annealing and extension) step.

Real time PCR was performed for HSV-1 using AmpliTaq Gold ${ }^{\circledR}$ PCR Master Mix (Roche, California, USA). Samples were tested in a $25 \mu \mathrm{l}$ reaction mix with $5 \mu \mathrm{l}$ nucleic acid, $11 \mu$ l Universal PCR Master Mix $2 \times, 2.5 \mu \mathrm{l}$ of each specific primer and probe set and $1.5 \mu \mathrm{l}$ nuclease free water.

Amplification was performed in same machine with slight modifications including $95{ }^{\circ} \mathrm{C}$ for $10 \mathrm{~min}$ then 40 cycles at $92{ }^{\circ} \mathrm{C}$ for $15 \mathrm{~s}$ (denaturing) and $60{ }^{\circ} \mathrm{C}$ for $1 \mathrm{~min}$ (annealing and extension step).

\section{Results and discussion}

Quantification of nucleic acids

The integrity of the nucleic acid extracted for the 80 CSF samples were of high quality with 77 having a high yield within the range of 53.2 to $101.4 \mathrm{ng} / \mu \mathrm{l}$ suitable for molecular studies when measured with the Nano Drop 2000c spectrophotometer. Three had the low yield being 20.5, 18.1 and $14.3 \mathrm{ng} / \mu \mathrm{l}$.

\section{Real time PCR}

In this study, the test run for each PCR performed involved test samples in duplicates with positive and negative controls to validate each test run. Until the positive and the negative control indicators are correctly shown after each run, the test cannot be considered valid. A repeat run was carried out in instances where none of the control indicators showed after the test run. All the PCR test runs for this work were validated.

None of the 80 suspected cases of meningitis investigated by PCR tested positive for EV, MuV and HSV-1 as no viral nucleic acid was detected. Figure 1 represents a PCR amplification plot of a test run with a detectable amplification for the positive control whilst the negative control and the samples included in the run were undetectable hence no amplification.

\section{Conclusion}

None of the viruses (EV, MuV, HSV-1) investigated in this study was detected in the suspected cases of meningitis. However, lymphocytic pleocytosis, normal glucose and elevated protein levels observed in majority of study participants.

\section{Limitations}

Our study could have been better but for some limitations. A larger and more representative sample size would have given a better information on the prevalence of the three viruses and interpretation of our results. Besides, the clinical and laboratory data for some of the patients were incomplete. Another noticeable limitation was the exclusion of other documented viral aetiologies for meningitis and a serological assay which would have

Table 2 PCR assays used in the study

\begin{tabular}{|c|c|c|c|}
\hline Virus & Primers oligosequences $\left(5^{\prime}-3^{\prime}\right)$ & Target region & References \\
\hline Enterovirus & $\begin{array}{l}\text { 5'-CCCTGAATGCGGCTAATCC-3', reverse primer, 5'-ATTGTCACCATAAGCAGCCA-3' and a probe, 5'-AACCGA } \\
\text { CTACTTTGGGTGTCCGTGTTTC-3' }\end{array}$ & $5^{\prime}$ UTR & {$[22]$} \\
\hline Mumps & $\begin{array}{l}\text { Forward primer (SH61F) 5'-GTGACCCTGCCGTTGCA-3', reverse primer (SH147R), 5'-GTTATGATCAGAGAGAGA } \\
\text { AGAATTAGCAATAG-3' and probe (SH79P2) 5'-TATGCCGGCGATCCAACCTCCCTTATA-3' }\end{array}$ & (SH) gene & {$[23]$} \\
\hline HSV-1 & $\begin{array}{l}\text { Forward primer (HSV1UP), 5'-CGGCCGTGTGACACTATCG-3', reverse primer (HSV1DP), 5'-CTCGTAAAATGG } \\
\text { CCCCTCC-3' and probe (HSV1P), 5'-CCATACCGACCACACCGACGAACC-3' }\end{array}$ & (gD) gene & {$[24]$} \\
\hline
\end{tabular}




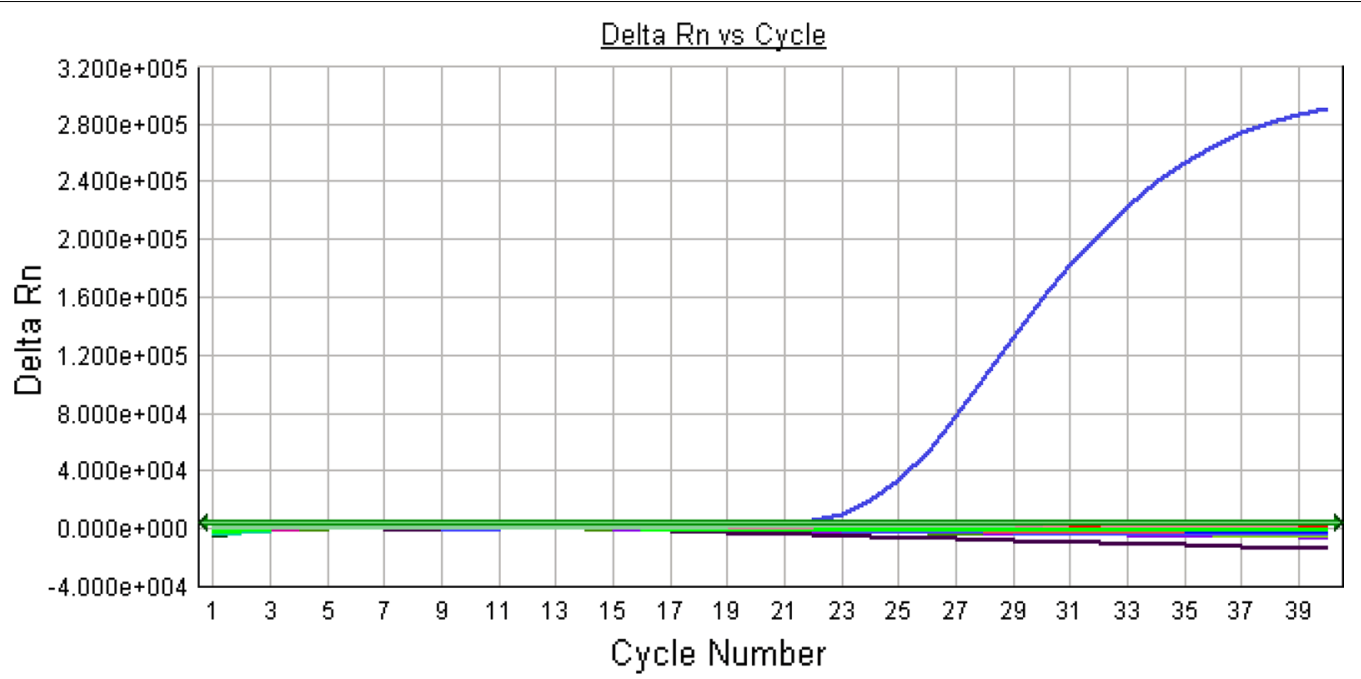

Fig. 1 Figure representing the amplification curve of the Real-time PCR runs for the samples and controls. The horizontal line with arrows represents the threshold. The curve that crossed the threshold represents the positive control. The samples and negative controls are below the threshold line (irregular lines) which represent a negative result. The amplification of the positive control depicts a successful PCR run

provided useful information on exposure levels of the patients to the viral agents.

\section{Abbreviations}

HIV: human immunodeficiency virus; EV: Enteroviruses; MuV: Mumps virus; HSV: Herpes Simplex Virus; CSF: cerebrospinal fluid; CNS: central nervous system; KBTH: Korle Bu Teaching Hospital; FU: Fevers Unit; PCR: polymerase chain reaction.

\section{Authors' contributions}

EFA, TKA and JHKB conceptualized and designed the study. EFA recruited the participants and collected the data. EFA, TKA, GM and JHKB processed and analyzed the data. EFA, TKA and JHKB interpreted the data. EFA and JHKB wrote the initial draft. TKA and GM revised the draft. All authors read and approved the final manuscript.

\section{Author details}

${ }^{1}$ Department of Medical Microbiology, School of Biomedical and Allied Health Sciences, College of Health Sciences, University of Ghana, Accra, Ghana.

${ }^{2}$ Noguchi Memorial Institute for Medical Research, College of Health Sciences, University of Ghana, Accra, Ghana.

\section{Acknowledgements}

We are grateful to Dr. Japhet Opintan for giving out the clinical specimens for the work, the staff of the Virology Department of Noguchi Memorial Institute for Medical Research for their support and technical assistance and to the staff of the Fevers' Unit of Korle Bu Teaching Hospital for their co-operation.

\section{Competing interests}

The authors declare that they have no competing interests.

\section{Availability of data and materials}

The datasets generated and/or analyzed during the current study are available from the corresponding author on reasonable request.

\section{Consent for publication}

Not applicable.

\section{Ethics approval and consent to participate}

The study was approved by the College of Health Sciences Ethical and Protocol Review Committee (PIN: CHS-Et/M.9-P 3.1/2015-2016). Patients' approvals for participation were obtained using written informed consent prior procedures. Patients were assigned study identification numbers which were used throughout the study. Patients' laboratory tests were not anonymized as these were required for routine patient care. All documents were kept confidential and only researchers involved in the study had access to study data.

\section{Funding}

This work was supported by funds from the Government of Ghana through a grant support from the University of Ghana Research Fund.

\section{Publisher's Note}

Springer Nature remains neutral with regard to jurisdictional claims in published maps and institutional affiliations.

Received: 18 June 2018 Accepted: 20 August 2018

Published online: 28 August 2018

\section{References}

1. Sundén B, Larsson M, Falkeborn T, Paues J, Forsum U, Lindh $M$, et al. Realtime PCR detection of Human Herpesvirus $1-5$ in patients lacking clinical signs of a viral CNS infection. BMC Infect Dis. 2011;11(1):220. http://www. biomedcentral.com/1471-2334/11/220.

2. Chadwick DR. Viral meningitis. Br Med Bull. 2005;75-76(1):1-14.

3. Tokuda Y. Bacterial versus viral meningitis: comparison of the old and the new clinical prediction models. Crit Care. 2000;4:1.

4. De Almeida SM, Savalla G, Gabardo BMA, Ribeiro CE, Rossoni AM, Araújo JMR. Acute bacterial meningitis in HIV patients in southern Brazil. Arq Neuropsiquiatr. 2007:65:273-8.

5. Kanji SS, Kakai R, Onyango RO. Cryptococcal meningitis among human immunodeficiency virus patients attending major hospitals in Kisumu, western Kenya. Arch Clin Microbiol. 2011;2(1):1-6.

6. Benjamin L, Kelly M, Cohen D, Neuhann F, Galbraith S, Mallewa M, et al. Detection of herpes viruses in the cerebrospinal fluid of adults with suspected viral meningitis in Malawi. Infection. 2013;41(1):27-31.

7. Vidal LRR, De Almeida SM, De Messias-Reason IJ, Nogueira MB, Debur MDC, Pessa LFC, et al. Enterovirus and herpesviridae family as etiologic agents of lymphomonocytary meningitis, southern Brazil. Arq Neuropsiquiatr. 2011;69(3):475-81. 
8. Nowak DA, Boehmer R, Fuchs HH. A retrospective clinical, laboratory and outcome analysis in 43 cases of acute aseptic meningitis. Eur J Neurol. 2003;10:271-80.

9. Newton PJ, Newsholme W, Brink NS, Manji H, Williams IG, Miller RF. Acute meningoencephalitis and meningitis due to primary HIV infection commentary : is testing for HIV without consent justifiable? BMJ. 2002:325:1225-7.

10. Wolthers KC, Benschop KSM, Schinkel J, Molenkamp R, et al. Human parechoviruses as an important viral cause of sepsis-like illness and meningitis in young children. Clin Infect Dis. 2008;47(3):358-63. https:// doi.org/10.1086/589752

11. Chambon M, Archimbaud C, Bailly JL, et al. Circulation of Enteroviruses and persistence of meningitis cases in the winter of 1999-2000. J Med Virol. 2001;65:340-7.

12. Ludlow M, Kortekaas J, Herden C, et al. Neurotropic virus infections as the cause of immediate and delayed neuropathology. Acta Neuropathol. 2016;131:159. https://doi.org/10.1007/s00401-015-1511-3.

13. St-martin G, Krause L, Neess F, Panum I, Andersen PHS, Rønn J, et al. Mumps resurgence in Denmark. J Clin Virol. 2014;61 (3):435-8. https://doi. org/10.1016/j.jcv.2014.08.013.

14. Kaewpoowat Q, Salazar L, Aguilera E, et al. Herpes simplex and varicella zoster CNS infections: clinical presentations, treatments and outcomes. Infection. 2016;44:337. https://doi.org/10.1007/s15010-015-0867-6.

15. Murphy RF, Caliendo AM. Relative quantity of cerebrospinal fluid Herpes Simplex Virus DNA in adult cases of encephalitis and meningitis. Am J Clin Pathol. 2009;132(5):687-90.

16. Davis $L E$, Tyler KL. Molecular diagnosis of CNS viral infections. J Neurol Neurosurg Psychiatry. 2004;76(1):10. http://jnnp.bmj.com/conte $\mathrm{nt} / 76 / 1 / 10$

17. Roa PL, Alonso R, De Egea V, Usubillaga R, Muñoz P, Bouza E. PCR for detection of Herpes Simplex Virus in cerebrospinal fluid: alternative acceptance criteria for diagnostic workup. J Clin Microbiol. 2013;51(9):2880-3.
18. Rhoades ER, Tabor-Godwin JM, Tsueng G, Feuer R, et al. Enterovirus infections of the central nervous system. Virology. 2011;411(2):288-305.

19. Commey JO, Rodrigues OP, Akita FA, Newman M. Bacterial meningitis in children in southern Ghana. East Afr Med J. 1994;71(2):113-7.

20. Opare J, Awoonor-Williams J, Odoom J, Afari E, Oduro A, Awuni B, et al. Bacterial meningitis: a review in the upper east region of Ghana 2010-2014. Int J Trop Dis Health. 2015;10(3):1-11. http://sciencedomain. org.

21. Nuoh RD, Nyarko KM, Nortey P, Sackey SO, Lwanga NC, Ameme DK, et al. Review of meningitis surveillance data, upper West Region, Ghana 2009-2013. Pan Afr Med J. 2016; 25(Supp 1):1-5. http://www.panafrican -med-journal.com/content/series/25/1/9/full.

22. Verstrepen WA, Kuhn S, Kockx MM, Van De Vyvere ME, Mertens AH. Rapid detection of enterovirus RNA in cerebrospinal fluid specimens with a novel single-tube real-time reverse transcription-PCR assay. J Clin Microbiol. 2001;39(11):4093-6.

23. Boddicker JD, Rota PA, Kreman T, Wangeman A, Lowe L, Hummel KB, et al. Real-time reverse transcription-PCR assay for detection of Mumps virus RNA in clinical specimens. J Clin Microbiol. 2007;45(9):2902-8.

24. Weidmann M, Meyer-könig U, Hufert FT. Rapid detection of Herpes Simplex Virus and Varicella-Zoster Virus infections by rapid detection of Herpes Simplex Virus and Varicella-Zoster Virus infections by real-time PCR. J Clin Microbiol. 2003;41 (4):1565-8.

25. Opintan JA, Awadzi BK, Biney IJK, Ganu V, et al. High rates of cerebral toxoplasmosis in HIV patients presenting with meningitis in Accra, Ghana. Trans R Soc Trop Med Hyg. 2017;111:464-71.

26. Kazuo I, Akira K, Shakashi N, Noburo M, et al. Application of coupled oxidation reaction to electron microscopic demonstration of horseradish peroxidase: cobalt-glucose oxidase method. Brain Res. 1979;175(2):341-6.

27. I wata J, Nishikaze O. New micro-turbidimetric method for determination of protein in cerebrospinal fluid and urine. Clin Chem. 1979;25(7):1317-9.
Ready to submit your research? Choose BMC and benefit from:

- fast, convenient online submission

- thorough peer review by experienced researchers in your field

- rapid publication on acceptance

- support for research data, including large and complex data types

- gold Open Access which fosters wider collaboration and increased citations

- maximum visibility for your research: over 100M website views per year

At BMC, research is always in progress.

Learn more biomedcentral.com/submissions 